UDC 582.542.11:577.133.5

\title{
Detection of stress resistance genes in transgenic maize by multiplex and touchdown polymerase chain reaction
}

\author{
M. A. Bannikova \\ Institute of Cell Biology and Genetic Engineering, NAS of Ukraine \\ 148, Akademika Zabolotnoho Str., Kyiv, Ukraine, 03680 \\ mbannikova@icbge.org.ua,molgen@icbge.org.ua
}

\begin{abstract}
Aim. To develop a methodology for detection of the genes of resistance to the stress factors in transgenic maize by multiplex (mPCR) and touchdown polymerase chain reactions. Methods. Isolation of total DNA by CTAB method, purification of DNA from RNA and proteins, electrophoresis of total DNA and amplification products in agarose gel, polymerase chain reaction. Results. The protocol of multiplex and touchdown polymerase chain reactions has been developed for simultaneous verification of the quality of total DNA extracted from the studied maize plant samples and detection of the genes that determine resistance to the stress factors in the transgenic maize and maize transformation events: BT176, MON810, MON88017, DAS1507, DAS59122, MIR604, GA21, NK603 (mPCR), Bt11, MON863, MON89034, T25 (touchdown PCR). The multiplex PCR and touchdown PCR were developed using the reference samples. Conclusions. The proposed protocol of $\mathrm{MPCR}$ and touchdown PCR reactions can be used for mass analysis of maize samples to detect the genes of tolerance/resistance to herbicides and genes of resistance to insects reliably, authentically, quickly and cheaply.
\end{abstract}

Ke yw or d s: genes detection, maize, multiplex and touchdown polymerase chain reaction.

\section{Introduction}

Maize is one of the most common cereal, forage and silage crops in the world. The transgenic plants of maize have been cultivated in the open system for more than 15 years, taking over $50 \%$ of arable land, suitable for this crop.

Not one, but several genes with their regulatory sequences are usually inserted into the maize genome. Such complex transformants, remarkable for their unique combination of genetic construction and genomic DNA of a transgenic plant, were called transformation events (Table 1).

The use of 12 main maize transformation events (Bt11, Bt176, DAS1507, GA21, MON810, MON863, NK603, T25, DAS59122, MON89034,
MON88017, MIR604) and their combinations is allowed in the EU countries by European Commission. Food and Feed Safety. Food Safety - From the Farm to the Fork (http://ec.europa.eu/food/dyna/gm_register/index_en.cfm).

According to different literature sources 5-10\% of the maize plants, cultivated in Ukraine, contain additional transgenes/transformation events. The majority of Ukrainian laboratories, analyzing the samples for transgenes (http://www.quality.ua), detect the presence of $35 \mathrm{~S}$ promoter or NOS terminator whereas the Joint Research Centre as European Union Reference Laboratory for GM Food and Feed (JRC) elaborated the protocols for quantitative detection of transgenes using Real-Time PCR [1]. Thus, our task was to develop a methodology of the

(C) 2015 M. A. Bannikova; Published by the Institute of Molecular Biology and Genetics, NAS of Ukraine on behalf of Biopolymers and Cell. This is an Open Access article distributed under the terms of the Creative Commons Attribution License (http://creativecommons.org/licenses/by/4.0/), which permits unrestricted reuse, distribution, and reproduction in any medium, provided the original work is properly cited 
fast, reliable, accurate and relatively cheap detection of the maize transformation events and included transgenes.

\section{Materials and Methods}

\section{Plant material}

The reference samples of maize, containing the corresponding transformation events, and the experimental selection samples of maize of the Researchand-Production Farm Mais Company (Ukraine) were studied in the work. All the samples were germinated for further DNA isolation.

\section{Isolation and purification of DNA}

Maize germ plants were ground in ceramic mortars with CTAB (20 g/l CTAB, $1.4 \mathrm{M} \mathrm{NaCl}, 0.1 \mathrm{M}$ Tris-HCl, $20 \mathrm{mM} \mathrm{Na} \mathrm{EDTA}_{2} \mathrm{pH}$ 8.0) and 1.4-mercaptoethanol. RNA treatment and triple purification from proteins and enzymes were performed using chloroform. The total DNA was salted out with isopropyl alcohol and washed with ethyl alcohol. The precipitate was dissolved in TE buffer, $\mathrm{pH}$ 8.0. The method of electrophoresis of nucleic acids in agarose gel was used to check the presence and quality of total plant DNA after the isolation procedure. The concentration of nucleic acids was measured spectrophotometrically. The purity of the total DNA was determined by the absorption ratio at the wavelength of 230, 260, $280 \mathrm{~nm}$. The DNA concentration of the samples was normalized to $30 \mathrm{ng} / \mu \mathrm{l}$ [2].

\section{Reaction mixtures}

The reaction mixtures, each of $20 \mu 1$, were prepared for the detection of transformation events. They included $1 \times$ DreamTaq $^{\mathrm{TM}}$ Green buffer (Thermo Scientific), $200 \mu \mathrm{M}$ dNTP, 0.5 unit of DreamTaq $^{\mathrm{TM}}$ (Thermo Scientific) polymerase, $30 \mathrm{ng}$

Table 1. Maize transformation events, registered in the $\mathbf{E U}$

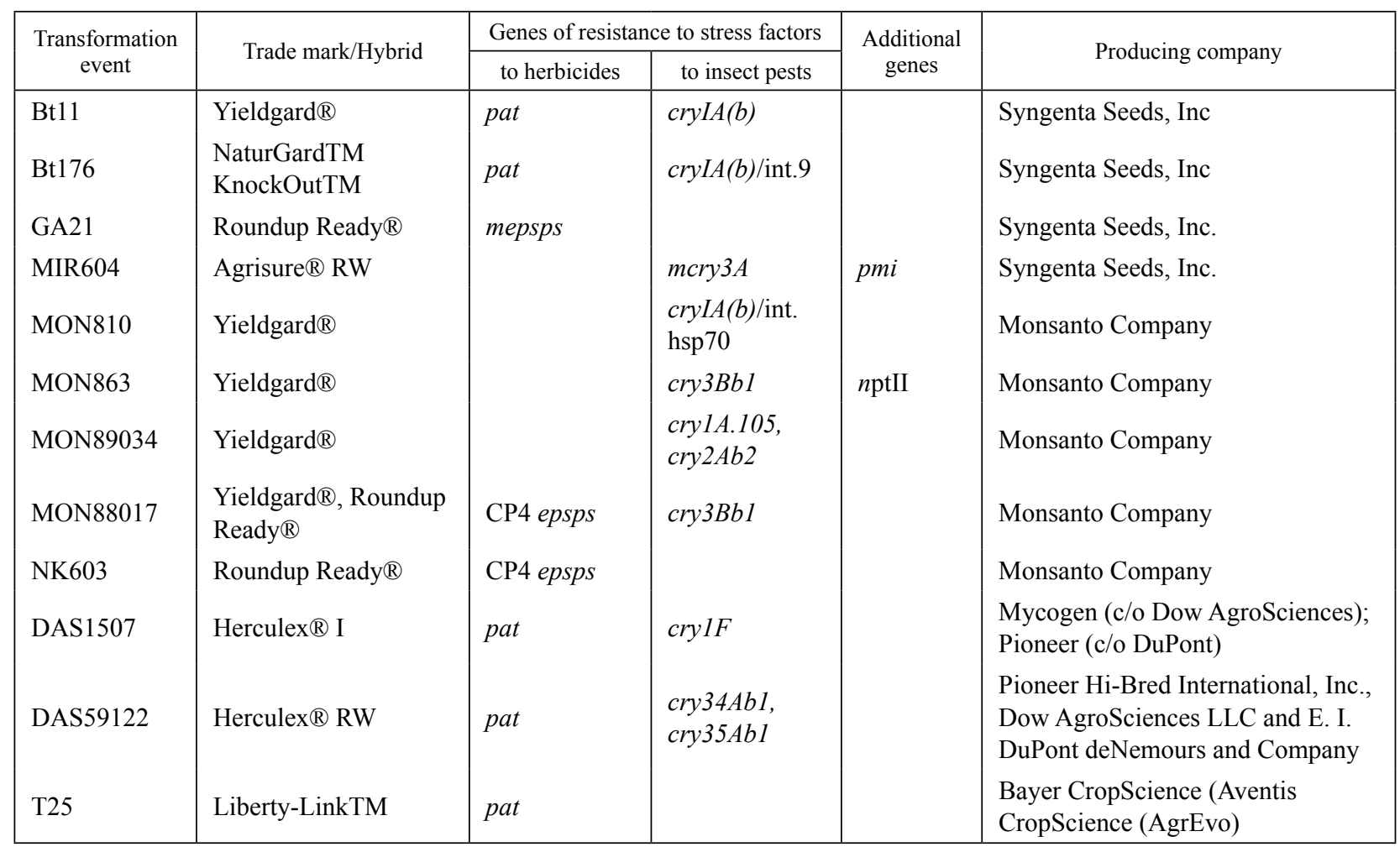

Note $p m i$ - gene of mannose 6-phosphate isomerase; $n p t \mathrm{II}$ - gene of neomycinphosphotransferase. 


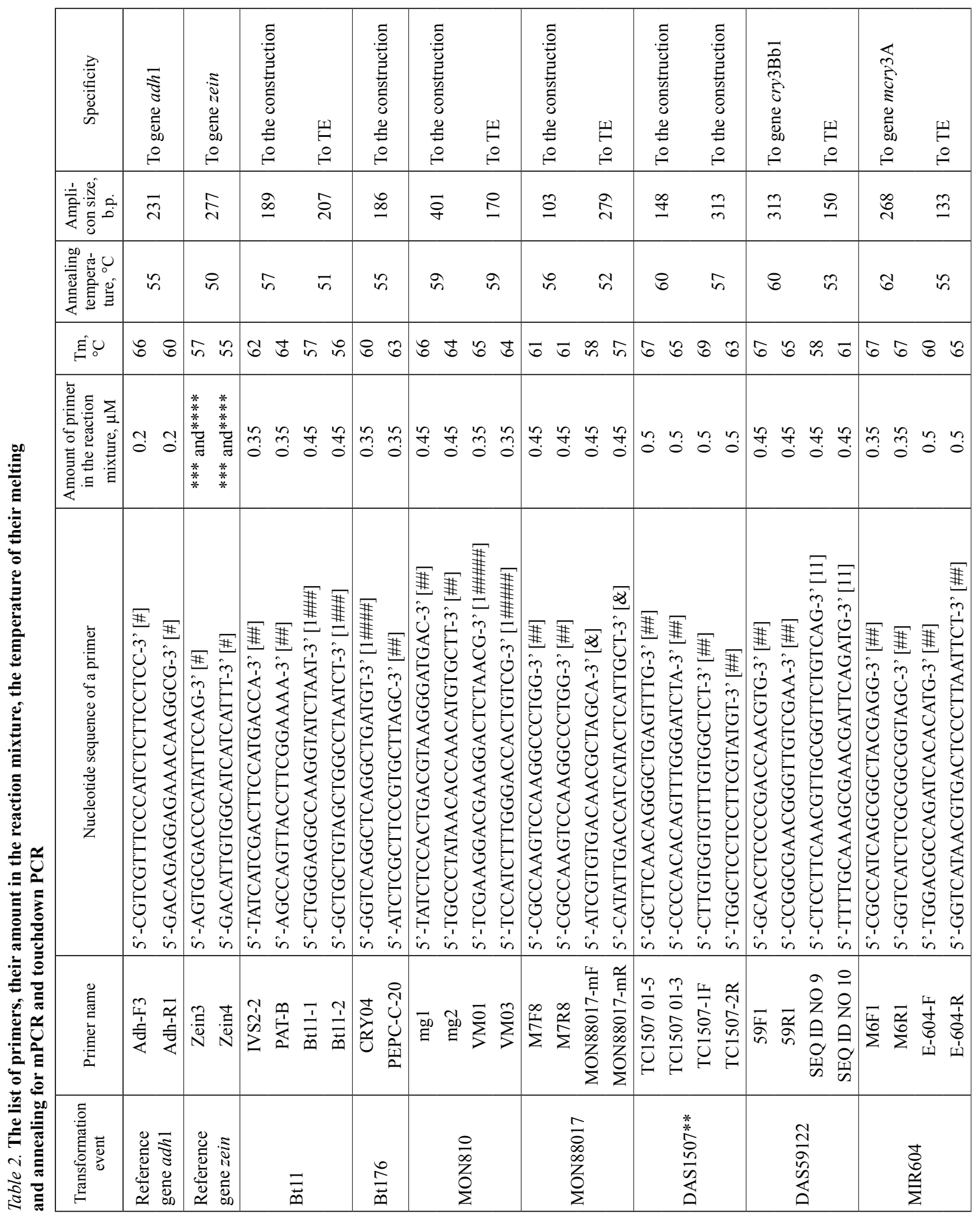




\begin{tabular}{|c|c|c|c|c|c|c|c|c|}
\hline 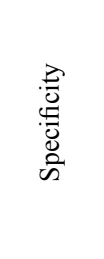 & $\begin{array}{l}\stackrel{I I}{\mid} \\
0 \\
0\end{array}$ & $\begin{array}{l}\stackrel{I I}{\boxminus} \\
0 \\
\ominus\end{array}$ & $\begin{array}{l}\stackrel{I I}{\boxminus} \\
0 \\
0\end{array}$ & 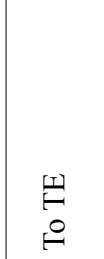 & 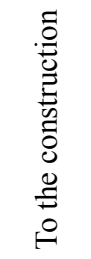 & 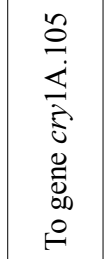 & 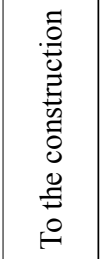 & $\stackrel{\dot{n}}{\vec{\omega}}$ \\
\hline 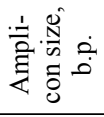 & 으 & $\stackrel{\infty}{0}$ & in & §్ & సे & $\stackrel{m}{i}$ & ڤें & $\sum_{j}^{0}$ \\
\hline 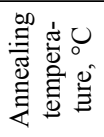 & กี & in & กิ & in & $g$ & 8 & it & 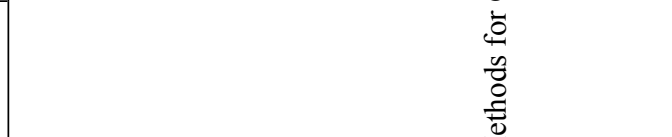 \\
\hline छี О & $\sigma$ in & $\mathbb{0} \quad$ & 8 in & in & in in & 68 & in 6 & छ \\
\hline 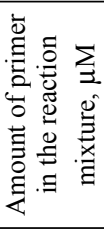 & $\stackrel{n}{f}: \frac{n}{f}$ & 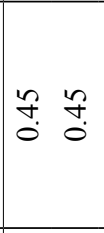 & $\stackrel{n}{\stackrel{n}{*}} \stackrel{?}{0}$ & $\begin{array}{ll}n & n \\
n & m \\
0 & 0\end{array}$ & $\stackrel{n}{n} \tilde{n}$ & $\begin{array}{ll}n & n \\
0 & \ddots \\
0\end{array} \mid$ & 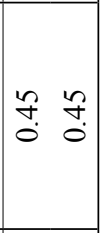 & 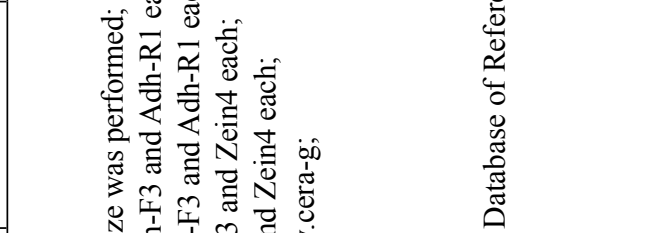 \\
\hline 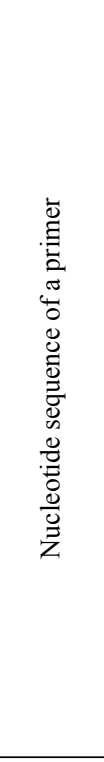 & 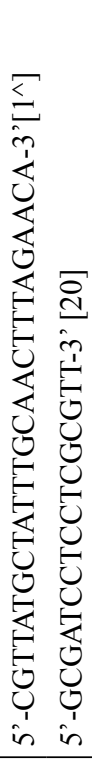 & 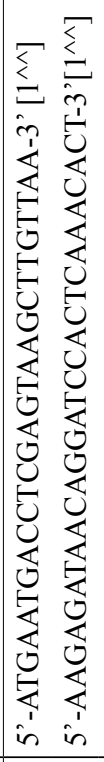 & 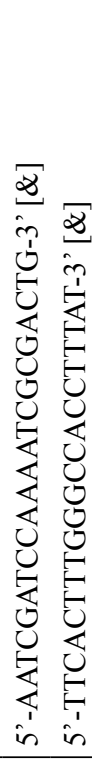 & 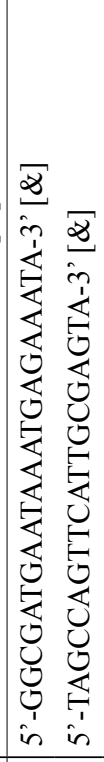 & 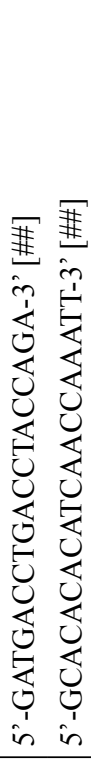 & 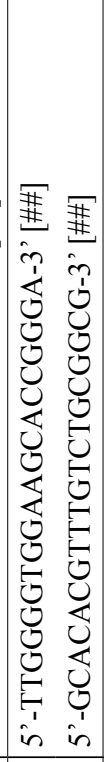 & 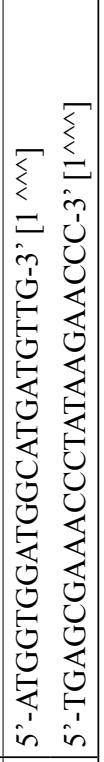 & 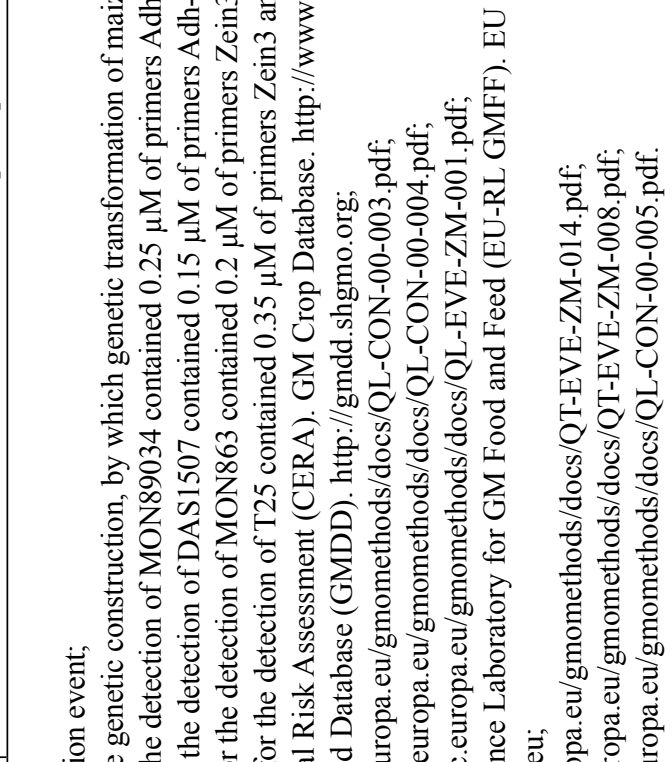 \\
\hline 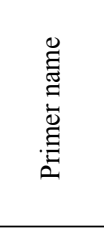 & 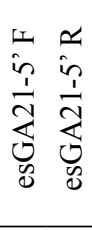 & 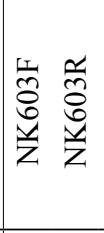 & 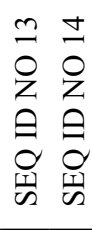 & 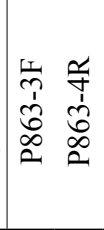 & 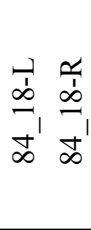 & 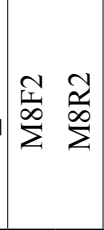 & 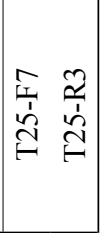 & 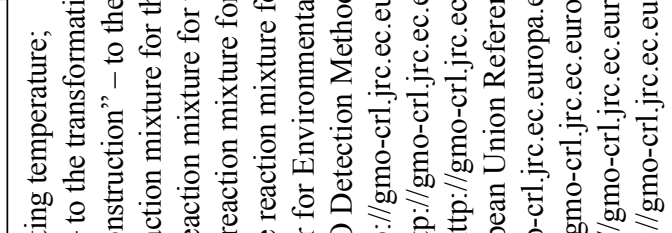 \\
\hline 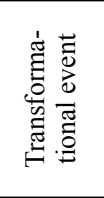 & 恿 & $z$ & & (2) & & 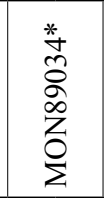 & $F$ & 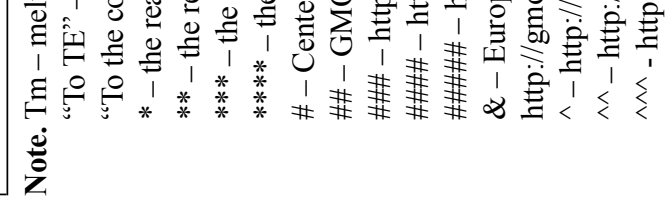 \\
\hline
\end{tabular}


of the plant DNA sample and primers to the reference gene (adh1; zein - for MON863 and T25) and to the transformation event under study. The concentration of primers was selected for each specific case depending on the specificity of binding to the DNA matrix (Table 2). The reaction mixture with $1 \mu 1$ of TE buffer ( $\mathrm{pH}$ 8.0) was used instead of the DNA sample as a negative control for all the cases.

\section{Polymerase chain reaction (PCR)}

PCR was conducted according to [3]. The conditions for the annealing stage were estimated in accordance with the properties of the oligonucleotide primers and their optimization was performed empirically.

\section{Electrophoresis}

The electrophoresis of amplification products was conducted according to [4]. $400 \mathrm{ng}$ of molecular mass marker O'GeneRuler ${ }^{\mathrm{TM}}$ DNA Ladder Mix (Thermo Scientific) were used as a marker. The gel plate was kept in ethidium bromide for the visualization of amplicons, shot by GelDoc ${ }^{\mathrm{TM}}$ (Bio-Rad) and processed using the GIMP graphic editor.

\section{Results and Discussion}

The genetically modified maize, containing individual transgenes, is an uncommon case. Practically all the transgenes are included in transformation events. The maize transformation events contain the

Table 3. Description of amplicons received in MPCR and touchdown PCR

\begin{tabular}{|c|c|c|}
\hline Transformation event & Size, bp & Description \\
\hline BT176 & 186 & Fragments of PSPC-promoter and cryIA(b) gene \\
\hline MON810 & $\begin{array}{l}170 \\
401 \\
645\end{array}$ & $\begin{array}{l}\text { Flanking region of plant DNA and a part of the genetic construct } \\
\text { Part of genetic construct } \\
\text { Region amplified by VM01 and mg2 primers, event-specific marker }\end{array}$ \\
\hline MON88017 & $\begin{array}{l}150 \\
313\end{array}$ & $\begin{array}{l}\text { Flanking region of plant DNA and a fragment of genetic construct } \\
\text { Fragment of the coding sequence of } c r y 3 B b 1 \text { gene }\end{array}$ \\
\hline DAS1507 & $\begin{array}{l}279 \\
103\end{array}$ & $\begin{array}{l}\text { Flanking region of plant DNA and a fragment of genetic construct } \\
\text { Fragment of genetic construct }\end{array}$ \\
\hline DAS59122 & $\begin{array}{l}148 \\
313\end{array}$ & $\begin{array}{l}\text { Fragment of } c r y 34 A b 1 \text { gene } \\
5 \text { ' Flanking region of plant DNA and a fragment of genetic construct }\end{array}$ \\
\hline MIR604 & $\begin{array}{l}133 \\
268\end{array}$ & $\begin{array}{l}\text { Flanking region of plant DNA and a fragment of genetic construct } \\
\text { Fragment of } c r y 3 \mathrm{~A} \text { gene }\end{array}$ \\
\hline GA21 & $\begin{array}{l}101 \\
231\end{array}$ & $\begin{array}{l}\text { Fragment of plant DNA along with a portion of Oryza sativa actins' promoter of genetic construct } \\
\text { Fragment of reference maize } a d h 1 \text { gene }\end{array}$ \\
\hline NK603 & $\begin{array}{l}501 \\
231 \\
108 \\
372\end{array}$ & $\begin{array}{l}\text { 5' Flanking region of plant DNA and a piece of genetic construct } \\
\text { Fragment of maize } a d h 1 \text { gene } \\
\text { 3' Flanking region of plant DNA and a fragment of genetic construct } \\
\text { Region between SEQ ID NO } 13 \text { and NK603F primers, event-specific marker }\end{array}$ \\
\hline BT11 & $\begin{array}{l}189 \\
231 \\
207\end{array}$ & $\begin{array}{l}\text { Fragment of adh1-enhancer and a part of pat gene of the transgenetic construct } \\
\text { Fragment of maize } a d h 1 \text { gene } \\
5 \text { ' Flanking region of plant DNA and a part of genetic construct }\end{array}$ \\
\hline MON863 & $\begin{array}{l}200 \\
277 \\
234 \\
526\end{array}$ & $\begin{array}{l}\text { Flanking region of plant DNA and a portion of genetic construct } \\
\text { Fragment of maize zein gene } \\
\text { Fragment of genetic construct } \\
\text { Region amplified by } 84 \text { 18-L and P863-4R primers, event-specific marker }\end{array}$ \\
\hline MON89034 & $\begin{array}{l}713 \\
231\end{array}$ & $\begin{array}{l}\text { Fragment of cry } 1 A .105 \text { gene and a part of genetic construct } \\
\text { Fragment of maize } a d h 1 \text { gene }\end{array}$ \\
\hline $\mathrm{T} 25$ & $\begin{array}{l}209 \\
277\end{array}$ & $\begin{array}{l}\text { Fragment of bar gene and a portion of T-35S terminator of the genetic construct } \\
\text { Fragment of maize zein gene }\end{array}$ \\
\hline
\end{tabular}


genes of resistance to insect pests and the genes of tolerance to herbicides (Table 1).

Gene pat (bar) encodes the enzyme phosphinothricin $\mathrm{N}$-acetyltransferase, determining the tolerance of plants to herbicides on the basis of phosphinothricin (PPT) - BASTA ${ }^{\mathrm{TM}}$, glufosinate, phosphinothricin.

Genes epsps, CP4 epsps (cloned from strain CP4 Agrobacterium tumefaciens) and mepsps (a mutant gene of maize) encode the enzyme 5-enolpiruvylshikimate-3-phosphate synthase (EPSPS), ensuring the tolerance to glyphosate (herbicide Roundup ${ }^{\mathrm{TM}}$ ).

Genes crylA(b), crylF, crylA.105, cry2Ab2, cry $3 B b 1, c r y 34 A b 1, c r y 35 A b 1$, cloned from the soil bacteria Bacillus thuringiensis, make the plants resistant to insect pests. The genes crylA(b), crylA.105 and $c r y 1 F$ ensure the resistance to the European maize borer (Ostrinia nubilalis), the genes cry34Ab1, cry$35 A b 1$, cry $3 B b 1$ and $m c r y 3 A$ - the resistance to the western maize rootworm (Coleoptera, Diabrotica spp.), cry $2 A b 2$ - the resistance to the pests of Lepidoptera class.

Our task was to determine the presence of sequences of transformation events or the genes thereof. Multiplex polymerase chain reaction (mPCR) and touchdown PCR, which allow the amplification of several DNA sites of specific length in one reaction, were developed to shorten the time, improve the reliability and quality of the PCR analysis [510]. This method presupposes the use of two (or more) pairs of oligonucleotide primers, specific to transformation events, and one pair of primers, specific to the maize reference gene $a d h 1$ (in some cases zein). Therefore, the selection of specific primers was conducted for each individual gene/transformation event (Table 2).

mPCR was used to detect the transformation events BT176, MON810, MON88017, DAS1507, MIR604, DAS59122, GA21, NK603 whereas no reliable results were obtained for detecting transformation events Bt11, MON863, MON89034 and T25. Therefore, the method of touchdown PCR was adapted to improve the quality and specificity of the reaction, to increase the amount of the amplified product and to neutralize the non-specific signals for the transformation events Bt11, MON863, MON89034 and T25.

The $a d h 1$ gene was used as a reference gene to detect all transformation events with the exception of MON863 and T25 [6, 7]. The amplicons of the events MON863 and T25 have sizes of $234 \mathrm{bp}$ and $209 \mathrm{bp}$ respectively, similar to the amplicon of $a d h 1$ (231 bp), that makes it complicated to distinguish and identify them using the gel-electrophoresis method. Thus, zein (277 bp) was used as a reference gene (Table 2).

The $\mathrm{mPCR}$ procedure of detection of the transformation events BT176, MON810, MON88017, DAS1507, MIR604, DAS59122, GA21, NK603 was as follows. The denaturation of plant DNA was performed at $94{ }^{\circ} \mathrm{C}$ for $4 \mathrm{~min}$ and consisted of 35 cycles, each of which included DNA denaturation at $94{ }^{\circ} \mathrm{C}$ for $30 \mathrm{~s}$. The time of the DNA renaturation with oligonucleotide primers was $30 \mathrm{~s}$. The synthesis of the fragments of target genes was performed at $72{ }^{\circ} \mathrm{C}$.

Table 4. The temperature of DNA renaturation with oligonucleotide primers and the time of synthesis of fragments of target genes

\begin{tabular}{|l|c|c|}
\hline $\begin{array}{c}\text { Transforma- } \\
\text { tion event }\end{array}$ & $\begin{array}{c}\text { The temperature of } \\
\text { DNA renaturation with } \\
\text { oligonucleotide prim- } \\
\text { ers, }{ }^{\circ} \mathrm{C}\end{array}$ & $\begin{array}{c}\text { The time of synthesis } \\
\text { of fragments of target } \\
\text { genes, s }\end{array}$ \\
\hline Bt176 & 55 & 18 \\
MON810 & 58 & 27 \\
DAS1507 & 55 & 20 \\
DAS59122 & 59 & 22 \\
MON88017 & 55 & 22 \\
MIR604 & 58 & 19 \\
GA21 & 56 & 17 \\
NK603 & 56 & 33 \\
BT11 & $65 / 51$ & 17 \\
MON863 & $66 / 52$ & 27 \\
MON89034 & $65 / 50$ & 20 \\
T25 & $65 / 50$ & 17 \\
BT11 & $65 / 50$ & \\
\hline
\end{tabular}



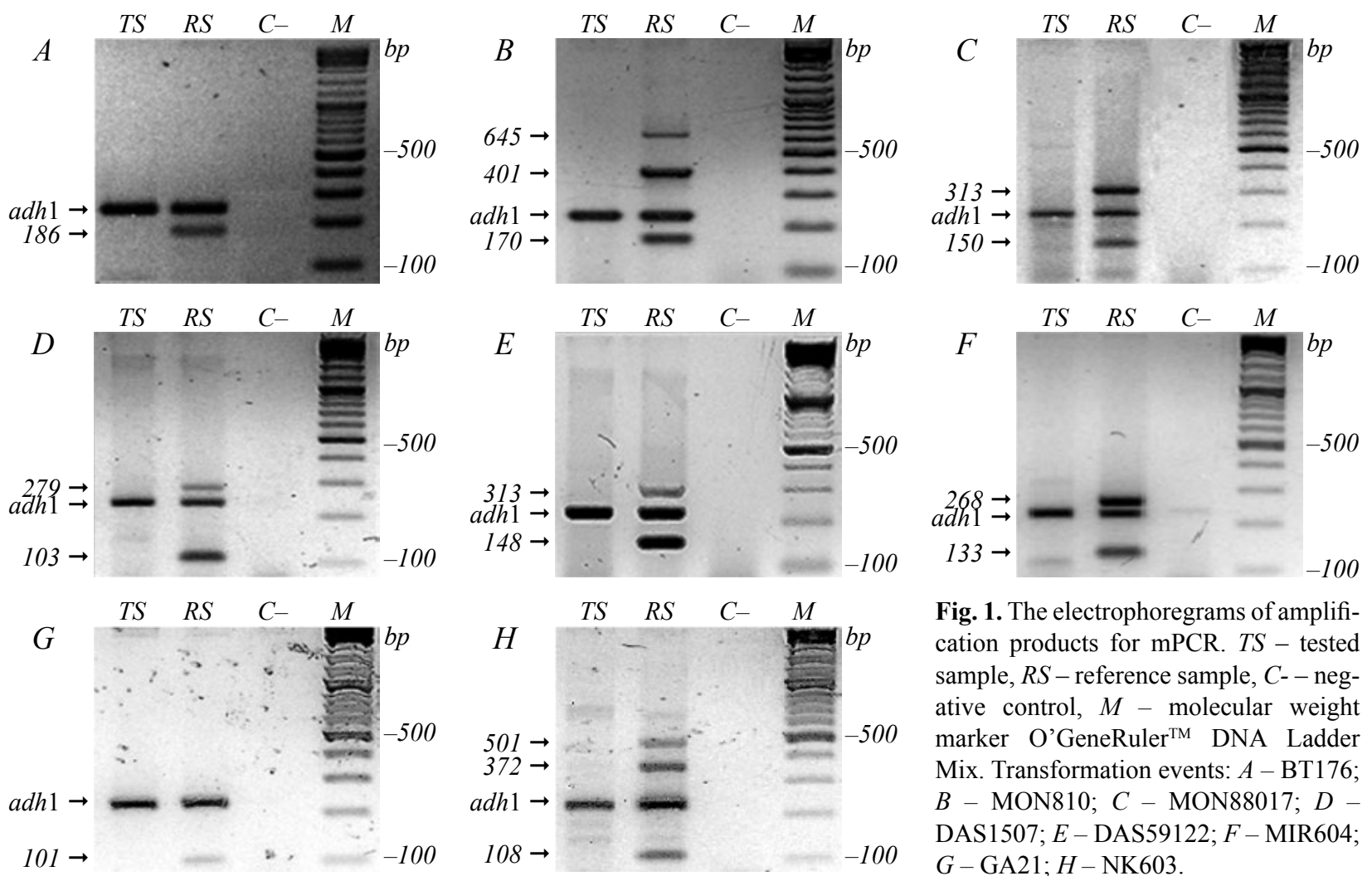

Fig. 1. The electrophoregrams of amplification products for MPCR. TS - tested sample, $R S$ - reference sample, $C$ - - negative control, $M$ - molecular weight marker O'GeneRuler ${ }^{\mathrm{TM}}$ DNA Ladder Mix. Transformation events: $A-\mathrm{BT} 176$; $B$ - MON810; $C$ - MON88017; $D-$ DAS1507; $E$-DAS59122; $F$ - MIR604; $G-\mathrm{GA} 21 ; H-\mathrm{NK} 603$.

The time of synthesis of the fragments of target genes and the temperature of DNA renaturation with synthesis of the fragments of target genes in all the oligonucleotide primers were selected individually reactions was conducted at $72{ }^{\circ} \mathrm{C}$ for $10 \mathrm{~min}$.

The method of touchdown PCR, used to detect the for each transformation event (Table 4). The final transformation events BT11, MON863, MON89034,
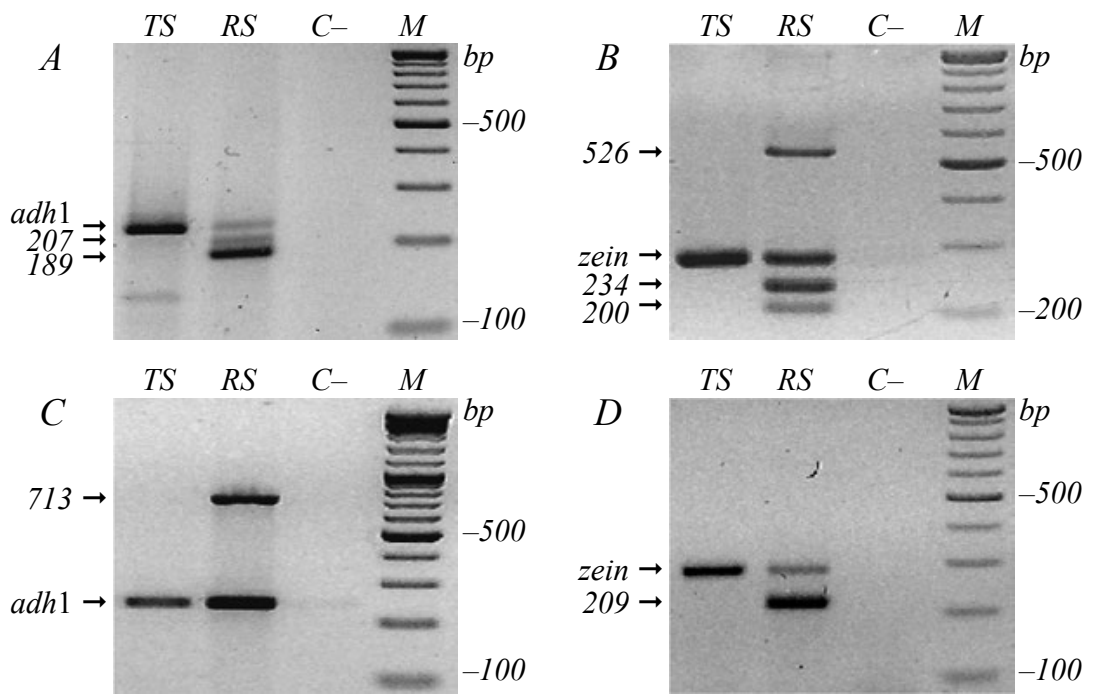

Fig. 2. The electrophoregrams of amplification products for touchdown PCR. $T S$ - tested sample, $R S$ - reference sample, $C$ - - negative control, $M$ - molecular weight marker O'GeneRuler ${ }^{\mathrm{TM}}$ DNA Ladder Mix. Transformation events: $A-$ BT11, $B-$ MON863, $C-$ MON89034, $D-\mathrm{T} 25$. 
T25, was similar to mPCR. The difference was that the initial annealing temperature for primers was $15^{\circ} \mathrm{C}$ higher than the expected melting temperature, during the first 15 cycles the annealing temperature was gradually (by $1{ }^{\circ} \mathrm{C}$ ) decreased until reaching the temperature, optimal for the tested pair of primers, and the next 21 cycles were performed at the optimal temperature, ensuring the exponential increase in the amount of target amplicon only.

PCR products were fragments of maize reference genes $a d h 1$ or zein and the target fragments of genes/ /transformation events/genetic constructions of specific length (Table 2, Figures 1 and 2).

It is evident in Figures 1 and 2 that the obtained amplicons correspond to the expected ones, referred in Table 2.

Maize $a d h 1$ or zein reference genes only were detected in the test samples; this testifies to the presence and quality of plant DNA in the samples and the absence of detected genes/transformation events in the genetic material of plants. Both marker genes of maize $a d h 1$ or zein and the amplicons of the expected size were detected in the reference samples, which testified to the adequacy of the selected conditions of $\mathrm{mPCR}$ and the presence of transformation events. The negative controls did not contain any fragments. This was the evidence of the purity of DNA reagents as well as the proper quality of reaction performance.

\section{Conclusions}

Therefore, the proposed protocol of $\mathrm{MPCR}$ and touchdown PCR allow investigators to minimize the time of research and the number of the reagents used. This makes it possible to check simultaneously isolated total DNA along with the reliable, accurate and efficient detection of the genes of resistance to the stress factors (tolerance/resistance to herbicides - pat (bar), epsps, CP4 epsps, mepsps and genes of resistance to insect pests - cryIA(b), crylA.105, cry2Ab2, cryIA(b)/int.9, cryIA(b)/int. hsp70, crylF, cry3Bb1, cry34Ab1, cry35Ab1, $m c r y 3 A)$ and the maize transformation events (BT176, MON810, MON88017, DAS1507,
DAS59122, MIR604, GA21, NK603, Bt11, MON863, MON89034 and T25).

The method may be applied in the mass analysis of maize samples. Neither transgenes, nor transformation events were detected among 200 samples of the experimental forms of maize of RPF Mais Company, which were analyzed.

\section{Acknowledgment}

I would like to thank A. V. Markovsky and B. V. Morgun for their comprehensive assistance in writing and preparing the article.

\section{Funding}

The work was completed in the framework of the scientific and technical project "The detection of genetic sequences, determining the qualitative characteristics of grain and resistance to stress factors, in maize" (registration number 0112U002802, 2012).

\section{REFERENCES}

1. European Commission, Joint Research Centre. Compendium of reference methods for GMO analysis. Publications Office of the European Union. 2010; 261 p.

2. Somma, M. Extraction and Purification of DNA. Session 4. In: Training Course on the Analysis of Food Samples for the Presence of Genetically Modified Organisms - User Manual. Eds M. Querci, M. Jermini, G. Van den Eede. European Commission, DG Joint Research Centre, Institute for Health and Consumer Protection. Luxembourg, 2006; 229 p.

3. Ausubel FM, Brent R, Kingston RE, Moore DD, Seidman $J G$, Smith JA, Struhl K. Eds. Current Protocols in Molecular Biology. John Wiley \& Sons Inc., 2003; 1600 p.

4. SambrookJ, Fritsch EF, Maniatis T. Eds. Molecular Cloning: A Laboratory Manual. Cold Spring Harbor Laboratory Press, Cold Spring Harbor, New York, USA, 2nd ed., 1989; 1234 p.

5. Yoke-Kqueen C, Yee-Tyan C, Siew-Ping K, Son R. Development of multiplex-PCR for Genetically Modified Organism (GMO) detection targeting EPSPS and Cryl Ab genes in soy and maize samples. International Food Research Journal. 2011; 18: 515-22.

6. Pat. 77768 of Ukraine, MPK C12N 15/31; C12N 15/32; C12N 15/82; C12Q 1/68; C12P 19/34. Method of detecting maize transformation event NK603 in a genetically modified plant by mPCR. Morgun BV, Fedorenko TV, Markovsky OV, Bannikova MO. No. u2012 10121; appl. dated August 23, 2012; publ. February 25, 2013, Bul. N 4. 
7. Pat. 77769 of Ukraine, MPK C12N 15/31; C12N 15/32; C12N 15/82; C12Q 1/68; C12P 19/34. Method of detecting maize transformation event NK603 in a genetically modified plant by mPCR. Morgun BV, Fedorenko TV, Markovsky OV, Bannikova MO. U. No. u2012 10122; appl. dated August 23, 2012; publ. February 25, 2013, Bul. No.4.

8. Huang HY, Pan TM. Detection of genetically modified maize MON810 and NK603 by multiplex and real-time polymerase chain reaction methods. J Agric Food Chem. 2004;52(11):3264-8.

9. Don RH, Cox PT, Wainwright BJ, Baker K, Mattick JS. 'Touchdown' PCR to circumvent spurious priming during gene amplification. Nucleic Acids Res. 1991;19(14):4008.

10. Hecker KH, Roux KH. High and low annealing temperatures increase both specificity and yield in touchdown and stepdown PCR. Biotechniques. 1996;20(3):478-85.

11. Pat. 0070139 USA. A01H 5/00, C12Q 1/68, C07H 21/04, C12N 15/82, C12N 5/04, A01H 1/00. Corn Event DAS59122-7 and Methods for Detection Thereof. Bing JW, Cressman RF JR, Gupta M, Hakimi SM at all; Pioneer HiBred international, Inc.; Dow AgroSciences LLC. E.I. DuPont deNemours and Company. Publ date Mar 30, 2006. Pub. No:US2006/0070139 A1.

\section{Детекція генів стійкості до стресових факторів у трансгенної кукурудзи за допомогою мультиплексної та низхідної полімеразних ланцюговоих реакцій}

М. О. Банникова

Мета. Розробити методику детекції генів стійкості до стресових факторів у трансгенної кукурудзи на основі мультиплексної (мПЛР) та низхідної (touchdown PCR) полімеразних ланцюгових реакцій. Методи. Виділення загальної ДНК ЦТАБ методом, очистка ДНК від білків та РНК, електрофорез загальної ДНК та продуктів ампліфікації в агарозному гелі, полімеразна ланцюгова реакція. Результати. Розроблено методики мПЛР та низхідної ПЛР, котрі дозволяють одночасно перевіряти якість загальної ДНК, яку виділили з досліджуваних рослинних зразків кукурудзи, та детектувати гени стійкості до стресових факторів, що входять до складу трансформаційних подій кукурудзи ВТ176, MON810, MON88017, DAS1507,
DAS59122, MIR604, GA21, NK603 (мПЛР) та Bt11, MON863, MON89034, T25 (низхідна ПЛР). мПЦР та низхідна ПЦР розроблені $з$ використанням референтних зразків. Висновки. Методика може бути використана для масового аналізу зразків кукурудзи. За допомогою мультиплексної та низхідної ПЛР можна надійно, достовірно, швидко та досить дешево виявляти гени толерантності/стійкості до гербіцидів і гени стійкості до комах шкідників.

Кл юч о в і с л о в а: детекція генів, кукурудза, мультиплексна та низхідна полімеразна ланцюгова реакція.

Детекция генов устойчивости к стрессовым факторам у трансгенной кукурузы с помощью мультиплексной и нисходящей полимеразных цепных реакций

М. А. Банникова

Цель. Разработать методику детекции генов устойчивости к стрессовым факторам у трансгенной кукурузы на основе мультиплексной (мПЦР) и нисходящей (touchdown PCR) полимеразных цепных реакций. Методы. Выделение общей ДНК ЦТАБ методом, очистка ДНК от белков и РНК, электрофорез общей ДНК и продуктов амплификации в агарозном геле, полимеразная цепная реакция. Результаты. Разработаны методики мПЦР и нисходящей ПЦР, позволяющие одновременно проверять качество общей ДНК, выделенной из исследуемых растительных образцов кукурузы, и детектировать гены устойчивости к стрессовым факторам, входящие в состав трансформационных событий кукурузы ВT176, MON810, MON88017, DAS1507, DAS59122, MIR604, GA21, NK603 (мПЦР) и Bt11, MON863, MON89034, T25 (нисходящая ПЦР). мПЦР и нисходящая ПЦР разработаны с использованием референтных образцов. Выводы. Методика применима для массового анализа образцов кукурузы. С помощью мультиплексной и нисходящей ПЦР можно надежно, достоверно, быстро и достаточно дешево выявлять гены толерантности/устойчивости к гербицидам и гены устойчивости к насекомым вредителям.

Кл юч ев ы е сл ов а: детекция генов, кукуруза, мультиплексная и нисходящая полимеразная цепная реакция.

Received 28.08.2015 